\title{
TANGGUNG JAWAB DAN WEWENANG NOTARIS/PPAT TERHADAP KEKELIRUAN DAN PEMBATALAN AKTA JUAL BELI TANAH
}

\author{
Yogi Kristanto, I Nyoman Putu Budiartha, Desak Gde Dwi Arini \\ Fakultas Hukum Universitas Warmadewa, Denpasar-Bali, Indonesia \\ yogikristanto55@gmail.com, budiartha59@gmail.com, arinidesak1966@gmail.com
}

\begin{abstract}
Abstrak
Notaris sebagai Pejabat Pembuat Akta Tanah merupakan tambahan kewenangan yang diberikan oleh undangundang untuk melakukan legalisasi atas pengikatan-pengikatan hukum yang dilakukan oleh masyarakat khususnya di bidang pertanahan. Oleh karena itu, kewenangan Notaris sebagai Pejabat Pembuat Akta Tanah ialah tidak membuat kekeliruan di dalam menerbitkan suatu akta autentik yang mengakibatkan kebatalan dan pembatalan suatu perikatan-perikatan yang dibuat. Kajian ini membahas dua isu: tanggung jawab dan wewenang Notaris sebagai Pejabat Pembuat Akta Tanah apabila kekeliruan atau pembatalan akta jual beli tanah terjadi dan akibat hukum apabila hal tersebut terjadi. Metode penelitian yang digunakan dalam penelitian ini adalah metode penelitian hukum normatif. Hasil penelitian menunjukkan bahwa pertanggungjawaban Notaris sebagai Pejabat Pembuat Akta Tanah terhadap kekeliruannya berwujud dalam pertanggungjawaban secara perdata berupa ganti rugi secara materiil dan imateriil, pertanggungjawaban secara pidana berupa sanksi kurungan minimal 6 tahun dan maksimal 8 tahun, dan pertanggungjawaban secara administratif berupa teguran tertulis sampai pemberhentian dengan tidak hormat. Akibat hukumnya ialah izin Notaris sebagai Pejabat Pembuat Akta Tanah dapat dicabut dan terhadap akta yang dibuatnya dapat dibatalkan atau batal demi hukum.
\end{abstract}

Kata Kunci: Tanggung Jawab; Notaris/PPAT; Kekeliruan; Akta Jual Beli; Tanah

\begin{abstract}
Notary as the Land Deed Official is an additional authority granted by law to carry out legalization of legal binding by the community, especially in the land sector. Therefore, the notary's authority as the Land Deed Official is not to make any mistake in issuing an authentic deed which results in the cancellation of the agreement made. This study discusses two issues: the liability and authority of the Notary as the official for making land deed if a mistake or cancellation of the land sale and purchase certificate occurs and the legal consequences if it has taken place. The research method used in this research is normative legal research method. The results of the research show that the liability of the Notary as the Land Deed Making Official for his / her mistakes is in the form of civil liability in the form of material and immaterial compensation, criminal liability in the form of imprisonment of at least 6 years and a maximum of 8 years, and administrative liability in the form of written warning to disrespect dismissal. The legal consequence is that the Notary's license as a Land Deed Official can be revoked and the land deed he has made can be canceled or null and void.
\end{abstract}

Keywords: Liability; Notary/PPAT; Mistake; Sale and Purchase Deed; Land

\section{PENDAHULUAN}

Semua manusia yang hidup di dunia ini memerlukan kebutuhan hidup, salah satunya adalah tanah yang merupakan unsur terpenting. Kebutuhan terhadap tanah dalam kehidupan manusia dari sejak lahir sampai meninggal manusia tidak bisa terlepas dari tanah, karena manusia dalam beraktivitas memperoleh bahan pangan dengan cara memperdaya gunakan tanah. Jadi keberadaan manusia sendiri tidak dapat terlepaskan dengan tanah. Karena begitu pentingnya tanah terhadap kehidupan manusia maka diperlukan serangkaian kegiatan untuk menata tanah yang tersedia melalui lembaga pemerintah yang berwenang dalam hal hak manusia/warga negara atas kepemilikan atas tanah-tanah yang tersedia, dan juga harus dibuatkan regulasinya terhadap manusia yang terkait dengan tanah tersebut, sehingga pemenuhan terhadap hak-hak kodrat itu sendiri dapat terlindungi secara adil dan mendapat 
kepastian hukum. Untuk menjamin adanya kepastian hokum maka pemerintah membuat profesi hukum guna membantu mereka yang kurang paham mengenai langkah-langkah hukum yang sebaiknya dilakukan dalam suatu kasus, demi terciptanya masyarakat yang cakap hukum. Profesiprofesi di bidang hukum yang dijumpai dalam masyarakat adalah advokat/pengacara serta Notaris/PPAT.

Notaris merupakan seseorang yang memiliki wewenang membuat akta autentik dan kewenangan yang lain sesuai dengan UUJNP. Pejabat Pembuat Akta Tanah (PPAT) merupakan jabatan dimana seseorang memiliki kewenangan membuat akta autentik mengenai hak atas tanah atau hak milik atas satuan rumah susun (Santoso, 2016). Dari penjelasan ini menunjukan bahwa kewenangan Notaris sebagai Pejabat Pembuat Akta Tanah (PPAT) untuk tidak membuat kekeliruan di dalam menerbitkan suatu akta autentik yang mengakibatkan kebatalan dan pembatalan suatu perikatan-perikatan yang dibuat.

Berikut ini akan dijelaskan contoh mengenai kekeliruan Notaris/PPAT yang berkaitan dengan penelitian ini. Seorang Notaris/PPAT dengan inisial A telah melakukan kekeliruan atau kesalahan dalam pembuatan akta jual beli dengan tidak melihat dokumen asli. Notaris/PPAT ini tidak mengindahkan tugasnya sebagai pejabat umum. Proses jual beli tanpa menyertakan dokumen asli dikatakan sebagai perbuatan melawan hukum dan tak sesuai dengan prosedur hukum. Notaris/PPAT dengan inisial A tersebut membuat akta jual beli hanya dengan dokumen fotokopi dan tidak mencocokkan dengan dokumen aslinya.

Sebagaimana dirumuskan peraturan pemerintah tentang pendaftaran tanah yakni PPAT wajib menolak membuat akta jika tidak disertakan sertifikat asli. Maka dari uraian di atas bahwa Notaris/PPAT tersebut telah melakukan kesalahan atau kekeliruan dengan tetap membuat akta hanya berdasarkan dokumen fotokopi tanpa mencocokkan dengan dokumen aslinya sehingga menyebabkan kerugian para pihak yang terdapat di dalamnya dan pembatalan terhadap akta jual beli tersebut.

Ada beberapa kajian tentang hubungan notaris dengan akta tanah atau jual beli tanah yang dilakukan. Beberapa di ataranya termasuk kajian yang dilakukan tentang keabsahan dan tanggung jawab PPAT terhadap akta jual beli tanah (Prawira, 2016). Selain itu, ada kajian tentang tanggung jawab notaris terhadap akta yang dibatalkan (Wardhani, 2017). Kajian berikutnya ialah kajian yang dilakukan terhadap akibat hukum pembatalan akta jual beli tanah (Clarista, 2018). Ada yang menakar kewenangan dan tanggung jawab PPAT dalam perspektif Bestuurs Bevoegdheid (Wibawa, 2019). Ada juga kajia tentang tanggung jawab PPAT dalam pembuatan akta jual beli tanah berdasarkan Peraturan Pemerintah Republik Indonesia Nomor 24 Tahun 2016 tentang PPAT (Febrina \& Sulaiman, 2019). Dan yang terakhir ialah kajian yang dilakukan untuk mengukur keabsahan dan tanggung jawab hukum atas akta jual beli tanah dengan pemalsuan identitas (Herwido dkk., 2020). Kajian-kajian ini memadai namun, sayangnya, tidak ada kajian yang mengungkap tanggung jawab PPAT terhadap kekeliruan dalam pembuatan akta tanah atau akta jual beli tanah.

Berkaitan denga fenomena di atas, penelitian ini mengkaji tentang: tanggung jawab dan wewenang Notaris sebagai PPAT apabila terjadi kekeliruan atau pembatalan akta jual beli tanah dan akibat hukum apabila Notaris sebagai PPAT melakukan kekeliruan dalam pembuatan akta jual beli tanah.

\section{METODE PENELITIAN}

Tipe penelitian yang digunakan dalam penulisan berupa penelitian hukum normatif, yakni penelitian yang dilakukan dengan mengkaji, meringkas dan ditambah dengan perundang-undangan yang mengatur khusus berkaitan dengan permasalahan yang di bahas dalam skripsi ini, pendekatan masalah yang digunakan berupa pendekatan konseptual dan perundang-undangan.

Untuk menunjang pengkajian terhadap permasalahan yang dijadikan sumber bahan hukum dan data diperoleh dari bahan hukum primeryang terdiri atas norma-norma ataupun kaidah yaitu pembukaan dan peraturan perundang-undangan yang sesuai dengan permasalahan yang dibahas, bahan hukum sekunder yang berupa penjelasan lebih lanjut tentang bahan hukum primer, bahan hukum tersier yang merupakan bahan yang menjelaskan tentang bahan hukum primer dan sekunder yang berkaitan dengan penelitian ini. 


\section{HASIL DAN PEMBAHASAN}

\section{Tanggung Jawab dan Wewenang Notaris sebagai PPAT apabila Terjadi Kekeliruan atau Pembatalan Akta Jual Beli Tanah}

Notaris bersumber dari bahasa Latin yakni Notariat, sedangkan Notaris dari Notarius (Notarui) didefinisikan "orang yang menjalankan pekerjaan menulis" (Notodisoerjo, 1982). Notaris menurut UUJNP adalah pejabat umum yang memiliki kewenangan dalam pembuatan akta autentik dan wewenang lainnya sesuai dengan undang-undang. Notaris dengan kewenangan untuk menjalankan kewajibannya sebagai pejabat pembuat akta tanah (PPAT) merupakan kewenangan lain yang dikehendaki undang-undang untuk melakukan pengesahan atas perikatan yang masyarakat lakukan termasuk di bidang pertanahan.

Maka dari itu, PPAT diangkat oleh negara dengan diberikannya tugas serta wewenang tertentu dalam memberikan pelayanan kebutuhan masyarakat terhadap akta pemindahan hak atas tanah, akta pembebanan hak atas tanah, dan akta pemberian kuasa pembebanan hak tanggungan sesuai yang diatur dalam peraturan perundang-undangan yang berlaku. Maksudnya adalah akta pemindahan dan pembebanan hak atas tanah dan Hak Milik Atas Satuan Rumah Susun dan akta pemberian kuasa untuk dibebankannya hak tanggungan. Artinya PPAT adalah pejabat yang bertugas membuat akta dengan maksud memindahkan hak atas tanah, memberikan hak baru dan membebankan hak atas tanahnya. Penerbitan akta jual beli yang dilakukan oleh Notaris/PPAT adalah atas permintaan orangorang yang menghadap kepadanya dalam rangka membuat kesepakatan dimana pihak 1 (satu) sepakat untuk menjual dan pihak yang lain sepakat untuk membeli suatu tanah dengan harga yang telah disepakati.

Berdasarkan KUH Perdata jual beli merupakan perjanjian antara para pihak yang menyerahkan benda dan membayar sesuai harga yang diperjanjikan. Maka jelas jual beli merupakan suatu sistem hukum yang mempunyai unsur-unsur seperti adanya penjual dan pembeli atau subjek hukum, kepentingan sendiri atau pihak lain atau status hukum, persetujuan penyerahan hak milik dan pembayaran atau peristiwa hukum, benda dan harga atau objek hukum, keterikatan kewajiban dan hak para pihak atau hubungan hokum (Muhammad, 2014).

Berdasarkan penjelasan diatas dapat diketahui bahwa akta jual beli tanah dapat juga menimbulkan kekeliruan apabila tidak sesuai dengan pasal 1457 dan tidak sesuai bentuk serta pejabat yang ditunjuk oleh undang-undang, yang mana kekeliruan tersebut adalah:

1. Subyeknya yang tidak sesuai dengan perjanjian dalam akta, artinya nama pemilik dari obyek tersebut salah.

2. Obyek yang dibuat dalam perjanjian tidak sesuai dengan yang sebenarnya atau obyek yang diperjanjikan sudah terikat dengan perjanjian yang lain.

3. Kedudukan pembuat akta jual beli tersebut wilayahnya berbeda dengan kedudukan obyek yang diperjanjikan.

4. Tanggal dan hari pada saat kedua belah pihak menghadap tidak sesuai dengan pernyataannya.

5. Kesalahan-kesalahan ketik didalam isi akta jual beli tersebut.

Jadi kekeliruan-kekeliruan yang dibuat dalam akta jual beli tersebut akan menyebabkan ke autentikannya menjadi penurunan status menjadi perjanjian juak beli di bawah tangan. Maka tanggung jawab apabila Notaris/PPAT melakukan kekeliruan dalam pembuatan akta jual beli antara lain:

1. Tanggung Jawab secara Perdata

Jika dalam membuat akta Notaris atau PPAT terdapat pihak yang rugi, baik kerugian secara materiil maupun imateriil maka pihak tersebut dapat mengajukan tuntutan secara perdata terhadap Notaris/PPAT yaitu dengan mengganti rugi segala kerugian yang di akibatkan oleh Notaris/PPAT tersebut.

2. Tanggung Jawab secara Pidana

Kesalahan secara pidana adalah apabila Notaris/PPAT melakukan tindakan hukum dalam hal ini adalah pemalsuan. Aturan pidana tidak tertulis dalam UU Jabatan Notaris, tapi melalui tanggung jawab pidana, seorang Notaris/PPAT yang melakukan tindak pidana dapat dijatuhkan sanksi berupa pemberhentian dengan tidak hormat sampai sanksi kurungan terhadap Notaris/PPAT tersebut. 
3. Tanggung Jawab Administratif

Dalam Pasal 85 UUJNP mengatur sanksi bagi Notaris berupa teguran lisan, teguran tertulis, pemberhentian sementara, pemberhentian dengan hormat, pemberhentian dengan tidak hormat.

Dari beberapa sanksi yang akan diberikan kepada Notaris itu, yang termasuk ke dalam sanksi administratif adalah pemberhentian sementara, pemberhentian dengan hormat, dan pemberhentian dengan tidak hormat (Adjie, 2013).

\section{Akibat Hukum Apabila Notaris sebagai PPAT yang Telah Keliru dalam Membuat Akta Jual Beli Tanah}

Menurut Ismail Saleh, ada empat pokok hal yang seharusnya diperhatikan oleh para Notaris/PPAT adalah sebagai berikut (Supriadi, 2015):

1. Dalam melaksanakan tugasnya, seorang Notaris/PPAT harus memiliki integritas moral yang mantap.

2. Notaris/PPAT harus jujur, tidak hanya pada diri sendiri tetapi juga pada klien nya.

3. Notaris/PPAT harus sadar akan batas wewenang-wewenangnya. Ia berkewajiban menaati ketentuan hukum yang berlaku tentang sebagaimana jauh ia bisa bertindak dan apa yang boleh serta apa yang tak bisa dilakukan.

4. Seorang Notaris/PPAT yang Pancasilais semestinya tetap berpegang teguh pada rasa keadilan hakiki.

Didasari oleh hal tersebut di atas, notaris sebagai PPAT dalam melaksanakan tugas-tugasnya wajib tunduk terhadap aturan-aturan yang mengatur tentang kewenangannya sebagai Pejabat Umum seperti yang dijelaskan di atas, sehingga kewenangannya tidak menimbulkan akibat hukum karena didalam melaksanakan tugasnya melanggar ketentuan-ketentuan seperti di atas, oleh karenanya Notaris dalam melaksanakan tugasnya sebagai PPAT tidak bisa terlepas dari aturan hukum dalam undang-undang mengenai Notaris dan peraturan pemerintah mengenai PPAT agar tidak menimbulkan akibat hukum sehingga menimbulkan pembatalan dan kebatalan demi hukum. Jenis-jenis sanksi hukum terhadap Notaris sebagai PPAT yang ditimbulkan akibat terjadinya kebatalan dan pembatalan akta jual beli tanah yaitu:

1. Sanksi Hukum secara Perdata

Jika Notaris/PPAT terbukti telah melakukan perbuatan melawan hukum dalam pembuatan akta dan membuat rugi salah satu pihak, maka pihak yang dirugikan dapat menyatakan pengajuan tuntutan ganti rugi kepada Notaris/PPAT. Kerugian yang dimaksud berupa kerugian materiil dan kerugian immateriil. Mengakibatkan akta yang dibuat oleh Notaris/PPAT batal demi hukum atau dapat dibatalkan.

2. Sanksi Hukum secara Pidana

Jika Notaris/PPAT melanggar ketentuan dalam KUHPidana dalam hal mengenai pemalsuan, maka Notaris/PPAT tersebut dapat dijatuhi hukuman berupa sanksi kurungan paling sedikit 6 tahun dan maksimal 8 tahun sesuai dengan ketentuan KUH Pidana.

3. Sanksi Hukum Secara Administratif

Jika dalam membuat akta Notaris/PPAT melanggar ketentuan dalam undang-undang mengenai jabatan notaris, peraturan pejabat pembuat akta tanah dan kode etik profesinya, maka Notaris akan terkena sanksi yang dimuat dalam pasal 85 UUJNP, berupa teguran lisan, sampai pemberhentian dengan tidak hormat.

Makna dari pemberhentian sementara di atas adalah apabila Notaris/PPAT telah melakukan pelanggaran ringan kepada larangan atau kewajibannya dalam jabatannya yakni Notaris/PPAT, berada di bawah pengampuan dan melakukan perbuatan tercela. Pemberhentian dengan hormat apabila Notaris/PPAT tersebut dikarenakan atas permintaannya sendiri dan/atau tidak lagi mampu mengemban tugasnya sebagai Notaris/PPAT karena keadaan kesehatan. Pemberhentian dengan tidak hormat apabila Notaris/PPAT melakukan pelanggaran berat terhadap larangan atau kewajibannya sebagai Notaris/PPAT dan/atau dijatuhkan pidana penjara berdasarkan putusan pengadilan sehingga mengakibatkan dapat dicabutnya izin terhadap Notaris/PPAT tersebut.

Dengan demikian berdasarkan kasus yang diangkat yaitu pembuatan akta jual beli hanya berdasarkan dokumen fotokopi tanpa melihat mencocokkan dengan dokumen asli. Sedangkan di dalam Peraturan Pemerintah tentang Pendaftaran Tanah mengatur tentang Notaris/PPAT menolak untuk membuatkan akta jika kepadanya tak disampaikan sertifikat asli sehingga mengakibatkan kebatalan 
dan pembatalan akta. Maka akibat hukum dari kasus tersebut, Notaris/PPAT dapat dikenakan sanksi hukum secara perdata yang berupa dapat dituntut mengganti kerugian oleh orang-orang yang dirugikan dari akta yang dibuat oleh Notaris/PPAT tersebut baik secara materiil maupun imateriil serta mengakibatkan akta yang dibuat oleh Notaris/PPAT bisa dibatalkan atau batal demi hukum dan/atau dapat dikenakan sanksi hukum secara administratif berupa teguran tertulis sampai pemberhentian dan pencabutan izin dari jabatannya sebagai PPAT.

\section{SIMPULAN DAN SARAN}

\section{Simpulan}

1. Bentuk tanggung jawab dari Notaris/PPAT apabila melakukan kekeliruan atas pembuatan akta jual beli tanah yakni secara perdata jika Notaris/PPAT melakukan perbuatan melawan hukum dalam membuat akta dan merugikan salah satu pihak baik kerugian secara materiil maupun imateriil, maka pihak-pihak yang dirugikan dapat mengajukan tuntutan ganti rugi kepada Notaris/PPAT yang bersangkutan. Jika dimata pidana seorang Notaris/PPAT terbukti melakukan pelanggaran ketentuan dalam KUHPidana dalam hal pemalsuan maka Notaris/PPAT tersebut dapat dituntut secara pidana dengan hukuman penjara minimal 6 (enam) tahun, maksimal 8 (delapan) tahun. Kemudian perihal administratif, apabila dalam pembuatan akta Notaris/PPAT melanggar ketentuan dalam UUJN-P, Peraturan Pejabat Pembuat Akta Tanah dan kode etik profesinya, maka Notaris/PPAT akan dikenai sanksi yang dimuat pada pasal 85 UUJN-P, berupa teguran lisan sampai dengan pemberhentian dengan tidak hormat sehingga menyebabkan dapat dicabutnya izin dari Notaris/PPAT tersebut.

2. Akibat hukum terhadap kekeliruan Notaris/PPAT dalam pembuatan akta jual beli tanah yaitu dapat dikenakan sanksi hukum secara perdata yang berupa tuntutan untuk mengganti kerugian oleh pihak-pihak yang dirugikan dari akta yang dibuat Notaris/PPAT tersebut baik secara materiil maupun imateriil serta mengakibatkan akta yang dibuat oleh Notaris/PPAT dapat dibatalkan atau batal demi hukum dan/atau dapat dikenakan sanksi hukum secara administratif berupa teguran tertulis sampai pemberhentian dan pencabutan izin dari jabatannya sebagai PPAT.

\section{Saran}

1. Kepada Notaris/PPAT sebagai lembaga yang berwenang dalam pembuatan akta jual beli tanah, hendaknya lebih teliti dalam membuat akta, mulai dari subjek, objek dan hal-hal yang berkaitan dengan pembuatan akta, supaya tidak terjadi kekeliruan yang dapat merugikan para pihak yang membuat perjanjian jual beli tanah.

2. Kepada Pemerintah agar menindak secara tegas perbuatan Notaris/PPAT yang melakukan pelanggaran-pelanggaran dalam melaksanakan tugas dan kewenangannya sebagai pejabat umum sehingga tidak menimbulkan kerugian bagi para pihak yang terlibat didalamnya.

\section{DAFTAR PUSTAKA}

Adjie, H. (2013). Sanksi Perdata dan Administratif terhadap Notaris sebagai Pejabat Publik. PT. Refika Aditama.

Clarista, L. (2018). Akibat Hukum Pembatalan Akta Jual Beli (AJB) Atas Tanah oleh Pejabat Pembuat Akta Tanah (PPAT) dalam Putusan Mahkamah Agung Nomor 888/K/Pdt/2016. Jurnal Hukum Adigama, 1(2), 253-275.

Febrina, D. T., \& Sulaiman, A. (2019). Tanggung Jawab Pejabat Pembuat Akta Tanah (PPAT) dalam Pembuatan Akta Jual Beli Tanah berdasarkan Peraturan Pemerintah Republik Indonesia Nomor 24 Tahun 2016 tentang PPAT (Studi Kantor Notaris \& PPAT Anita Mahdalena, SH). PETITA, $1(1), 123-156$.

Herwido, L. P., Suryandono, W., \& Wiryomartani, W. (2020). Keabsahan dan Tanggung Jawab Hukum atas Akta Jual Beli dengan Pemalsuan Identitas Penghadap Dan Kuasa yang Cacat Hukum. Notary Indonesia, 2(1).

Muhammad, A. (2014). Hukum Perdata Indonesia. Citra Aditya Bakti.

Notodisoerjo, R. S. (1982). Hukum Notariat di Indonesia Suatu Penjelasan. Rajawali Pers.

Prawira, I. G. B. Y. (2016). Tanggung Jawab PPAT terhadap Akta Jual Beli Tanah. Jurnal IUS Kajian Hukum Dan Keadilan, 4(1), 66-78.

Santoso, U. (2016). Pejabat Pembuat Akta Tanah: Perspektif Regulasi, Wewenang, dan Sifat Akta. 
Predana Media.

Supriadi. (2015). Etika \& Tanggung Jawab Profesi Hukum di Indonesia. Sinar Grafika.

Wardhani, L. C. (2017). Tanggung Jawab Notaris/PPAT terhadap Akta yang Dibatalkan oleh Pengadilan. Lex Renaissance, 1(2), 49-63.

Wibawa, K. C. S. (2019). Menakar Kewenangan dan Tanggung Jawab Pejabat Pembuat Akta Tanah (PPAT) dalam Perspektif Bestuurs Bevoegdheid. Jurnal CREPINDO, 01(01), 40-51.

Kitab Undang-Undang Hukum Perdata

Undang-Undang RI Nomor 5 Tahun 1960 tentang Peraturan Dasar Pokok-Pokok

Agraria.

Undang-Undang Nomor 2 Tahun 2014 tentang Perubahan atas Undang-Undang

Nomor 30 Tahun 2004 Tentang Jabatan Notaris.

Peraturan Pemerintah Republik Indonesia Nomor 24 Tahun 2016 tentang Perubahan atas Peraturan Pemerintah Nomor 37 Tahun 1998 tentang Peraturan Jabatan Pejabat Pembuat Akta Tanah (PPAT).

Peraturan Pemerintah Nomor 24 Tahun 1997 tentang Pendaftaran Tanah. 